\title{
KARAKTERISASI DAN PENAPISAN AKTIVITAS ANTIBAKERI ISOLAT BAKTERI SIMBION Thurudilla lineolata DAN Phyllidiella pustulosa
}

\author{
(Characterization and Screening Antibacterial Activity of Thurudilla lineolata and \\ Phyllidiella pustulosa Symbiont Bacteria Isolate)
}

\author{
Kevien Marthin Doringin, Rosita A. J. Lintang ", Deiske A. Sumilat \\ Remy E.P. Mangindaan, Losung Fitje
}

Program Studi Ilmu Kelautan, Fakultas Perikanan dan Ilmu Kelautan, Universitas Sam Ratulangi, Manado

*Email: rositalintang@unsrat.ac.id

\begin{abstract}
Nudibranch are part of a class og Gastropods that do not have a shell and has a bright and striking colour. Nudibranch has different of bacteria and bioactive compounds contained therein for protect theselves from predators. The aim of this study were to isolate symbiotic bacterial drived from Thurudilla lineolata and Phyllidiella pustulosa, and to observe the antibacterial activity of bacterial isolate against Escherichia coli and Staphylococcus aureus. Isolation and culture of the symbiotic bacterial were made on Nutrient Agar. The antibacterial screening showed that Thrudilla lineolata and Phyllidiella pustulosasymbiotic bacteria were able to inhibit the growth of against Escherichia coli and Staphylococcus aureus
\end{abstract}

Nudibranch merupakan bagian dari kelas Gastropoda yang tidak memiliki cangkang dan memiliki warna cerah dan mencolok. Nudibranch memiliki berbagai jenis bakteri dan senyawa bioaktif yang terkandung di dalamnya untuk melidungi diri dari predator. Tujuan dari penelitian ini yaitu untuk mendapatkan isolat bakteri yang bersimbion dengan Thrudilla lineolata dan Phyllidiella pustulosa, kemudian mengamati aktivitas antibakteri dari isolat bakteri tersebut terhadap Escherichia coli, dan Staphylococcus aureus. Isolasi dan kultur bakteri yang bersimbion dengan Thrudilla lineolata dan Phyllidiella pustulosa, dibuat pada media Nutrient Agar. Skrining aktivitas antibakteri menunjukkan isolat bakteri yang bersimbion dengan Thrudilla lineolata dan Phyllidiella pustulosa mampu menghambat pertumbuhan organisme uji Staphylococcus aureus dan Escherichia coli.

Kata kunci: Nudibranch, Thrudilla lineolata, Phyllidiella pustulosa, bakteri, isolasi, antibakteri 


\section{PENDAHULUAN}

Nudibranch merupakan bagian dari kelas Gastropoda yang tidak memiliki cangkang dan memiliki warna cerah dan mencolok (Karuso and Scheuer, 2002). Nudibranch memiliki berbagai jenis bakteri dan senyawa bioaktif yang terkandung di dalamnya, dalam hal ini Nudibranch menghasilkan senyawa kimia untuk melidungi dirinya dari predator.

asosiasi dengan moluska laut memungkinkan pengunaan moluska laut menjadi sumber bakteri yang baru (Pringgenies, 2010). Senyawa bioaktif tersebut diduga memiliki potensi dalam bidang farmasi bahari, namun ketersediaan organisme yang sangat terbatas yang dapat menjadi masalah baru yang akan timbul. Oleh karena itu pemanfaatan mikroorganisme simbion menjadi alternatif dalam masalah terbatasnya organisme (Pringgenies, 2009).

Senyawa bioaktif yang diekstrak secara besar-besaran dari organisme laut akan merusak keberadaan organisme itu sendiri dan bertentangan dengan kepentingan konservasi (Pastra dkk., 2012). Oleh sebab itu, eksplorasi bakteri simbion dari Nudibranch perlu dilakukan. Selain itu, berbagai penyakit yang disebabkan oleh bakteri pada saat ini semakin banyak dan diperlukan pencarian senyawa antibakteri baru.
Tujuan Penelitian: Tujuan yang hendak dicapai dalam penelitian ini yaitu untuk mendapatkan bakteri simbion Thurudilla lineolata dan Phyllidiella pustulosa dan melakukan skrining aktivitas antibakteri dari isolat bakteri tersebut terhadap Escherichia coli, dan Staphylococcus aureus.

\section{METODE PENELITIAN}

Pengambilan dan Identifikasi Sampel

Sampel untuk penelitian ini diperoleh dari Perairan Pantai Bulo Desa Tateli Kec. Mandolang Kab. Minahasa, Sulawesi Utara. (Gambar 1)

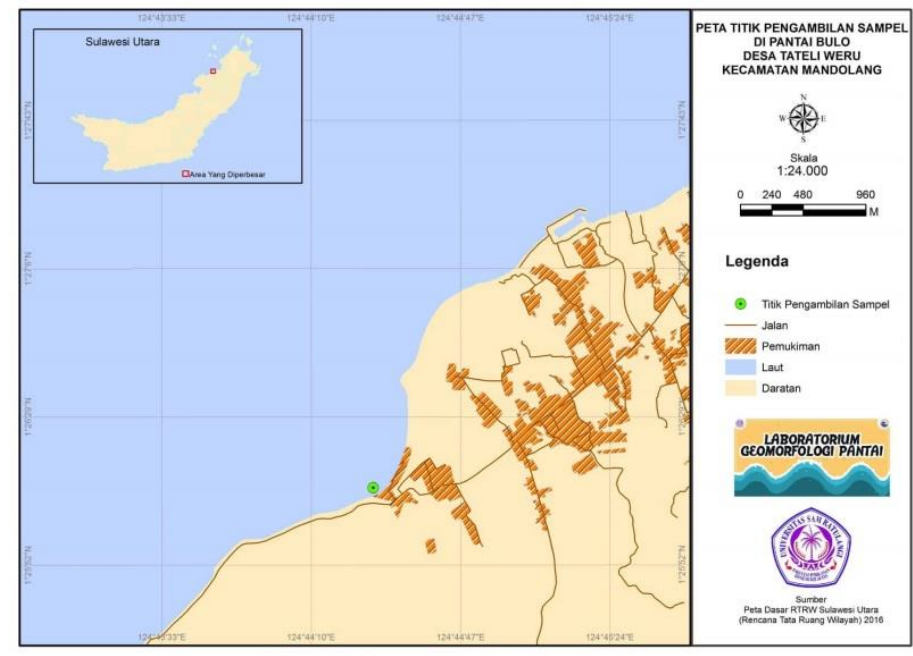

Gambar 1. Peta Lokasi Penelitian 
Penyelaman dilakuan disekitar terumbu karang yang diduga merupakan habitat nudibranch pada kedalaman 3-10 meter menggunakan alat scuba individu nudibranch diambil menggunakan pinset dan langsung dimasukan kedalam plastic sampel selanjutnya dibawa ke Laboratorium Biologi Molekuler dan Farmasetika Laut Fakultas Perikanan dan IImu Kelautan UNSRAT untuk penelitian lebih lanjut. Sampel nudibranch diidentifikasi berdasarkan Gosliner at.al (2018) dan WoRMS (World Register of Marine Spesies).

\section{Sterilisasi Alat dan Bahan}

Alat-alat yang digunakan pada penelitian ini seperti tabung reaksi, cawan petri, dan beberapa peralatan lainnya disterilkan dalam oven pada suhu $160^{\circ} \mathrm{C}$ selama \pm 120 menit. Sterilisasi media dilakukan dengan otoklaf pada suhu $121^{\circ} \mathrm{C}$ selama 20 menit.

\section{Pembuatan Media NA (Nutrien Agar)}

Media NA ditimbang sebanyak 5,6 gram dimasukkan kedalam erlenmeyer dan ditambahkan $200 \mathrm{ml}$ air lau steril $50 \%$. Selanjutnya media disterilkan dalam otoklaf pada suhu $121^{\circ} \mathrm{C}$ selama 20 menit dan dalam keadaan hangat dituang ke dalam cawan petri, dibiarkan sampai media mengeras.

\section{Isolasi Sampel dengan Metode Pengenceran}

Sampel yang didapat dipotongpotong lalu dige Sampel Nudibranch dipotong-potong lalu digerus dengan mortar, setelah itu dimasukkan ke dalam erlenmeyer berisi $10 \mathrm{ml}$ air laut steril diaduk perlahan hingga homogen (konsentrasi $10^{\circ}$ ). Dari konsentrasi ini sampel diencerkan ke dalam $9 \mathrm{ml}$ media baru (konsentrasi 10 $0^{-1}$ ), dilanjutkan pengenceran tersebut sampai konsentrasi $10^{-4}$.

Sampel dari masing-masing konsentrasi dituang kedalam media NA dengan metode sebar (Spread Plate Method) dan diinkubasi 1×24 jam untuk melihat pertumbuhan bakteri

\section{Isolasi dan Pemurnian Bakteri Pada Media NA}

Isolasi bakteri pada media padat dilakukan berdasarkan panduan buku "Microbiology Laboratory Manual" (Varghese and Joy, 2014). Koloni sampel hasil dari metode sebar (Spread Plate Method) yang masih padat selanjutnya digores kuadran dengan metode Streak plate method untuk mendapatkan isolat koloni yang terpisah yang disebut koloni tunggal.

\section{Identifikasi Morfologi Koloni dan Sel Isolat}

Identifikasi morfologi koloni isolat murni dilakukan dengan mengamati bentuk koloni, permukaan koloni, elevasi, tepi koloni, warna koloni, dan pigmentasi. Identifikasi sel secara mikroskopik yaitu mengamati bentuk dan warna sel yang telah dilakukan metode pewarnaan Gram di bawah mikroskop.

\section{Skrining Aktivitas Antibakteri Isolat Bakteri Simbion}

Skrining antibakteri dilakukan terhadap isolat murni yang diperoleh untuk mengetahui isolat mana yang memiliki aktivitas antibakteri. Bakteri uji yang digunakan adalah $S$. aureus dan $E$. coli yang telah dicampurkan ke dalam 
media NA yang telah disiapkan sebelumnya. Isolat murni ditotolkan pada permukaan media NA yang telah mengandung bakteri uji dan diinkubasi selama 1×24 jam kemudian lakukan pengamatan. Adanya zona hambat (inhibitory zone/clear zone) merupakan tanda adanya kepekaan terhadap bakteri uji.

\section{HASIL DAN PEMBAHASAN}

\section{Identifikasi Organisme Nudibranch}

Sampel yang diperoleh dari perairan Pantai Buloh terdapat dua jenis. Jenis pertama dengan ciri-ciri yaitu memiliki ujung berwarna hijau, bagian mantel berwarna hitam dan panjang tubuh $4 \mathrm{~cm}$, teridentifikasi sebagai Phylidiella pustulosa. Jenis kedua teridentifikasi sebagai Thurudilla lineolata dengan ciri-ciri yaitu tubuh sangat ramping berwarna biru cerah, pola berwarna oranye, terdapat garis melingkar di sepanjang tubuh (Gambar 2).
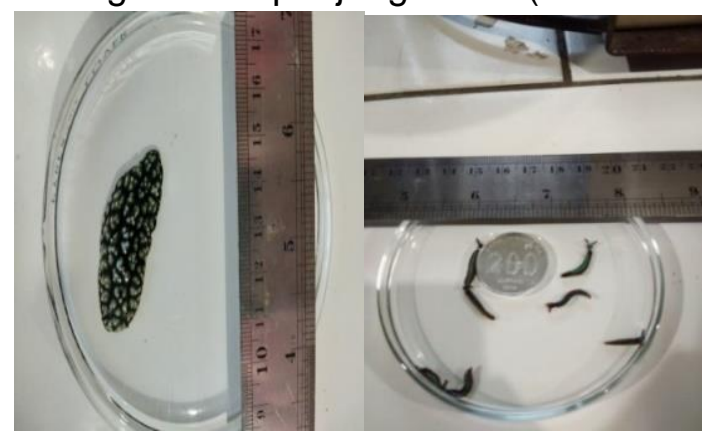

Gambar 2. Organisme hasil sampling Phylidiella pustulosa dan Thrudilla lineolata.

\section{Isolasi dan Pemurnian Bakteri}

Hasil kultur dari metode pengenceran bakteri dari Phylidiella pustulosa dan Thurudilla lineolata terlihat munculnya gumpalan berwarna putih susu yang menandakan adanya pertumbuhan dari bakteri yang bersimbiosis dengan Phylidiella pustulosa dan Thurudilla lineolate (Gambar 3).

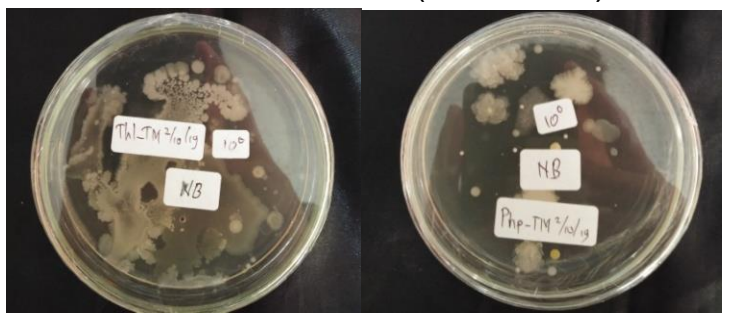

Gambar 3. Isolasi bakteri Thrudilla lineolate dan Phylidiella pustulos

Pemurnian dengan gores kuadran menghasilkan koloni tunggal yang selanjutnya diberikan kode pada setiap cawan petri dan dihitung jumlahnya (Tabel 1)

Tabel .1 Jumlah Koloni Tunggal bakteri simbion Thurudilla lineolata (Thl-TM) dan Phyllidiella pustulosa(Php-TM)

\begin{tabular}{|c|c|}
\hline Kode Sampel & Jumlah Koloni Tunggal \\
\hline Thl-TM. 0.1 & 10 \\
\hline Thl-TM.0.2 & 7 \\
\hline Thl-TM.0.3 & 18 \\
\hline Thl-TM.1.1 & 3 \\
\hline Thl-TM.2.1 & 8 \\
\hline
\end{tabular}




\begin{tabular}{|c|c|}
\hline Thl-TM.2.2 & 6 \\
\hline Thl-TM.2.3 & 11 \\
\hline Thl-TM.3.1 & 7 \\
\hline Thl-TM.4.1 & 13 \\
\hline Php-TM.0.1 & 4 \\
\hline Php-TM.0.2 & 11 \\
\hline Php-TM.3.1 & 12 \\
\hline Php-TM.3.2 & 18 \\
\hline TOTAL & 128 \\
\hline
\end{tabular}

\section{Identifikasi Morfologi Koloni Tunggal}

Berdasarkan identifikasi morfologi koloni tunggal didominasi oleh bentuk bulat sebanyak 8 isolat, ketinggian datar 6 isolat, pinggiran bergelombang 4 isolat dan warna koloni putih susu 9 isolat (Gambar 4)

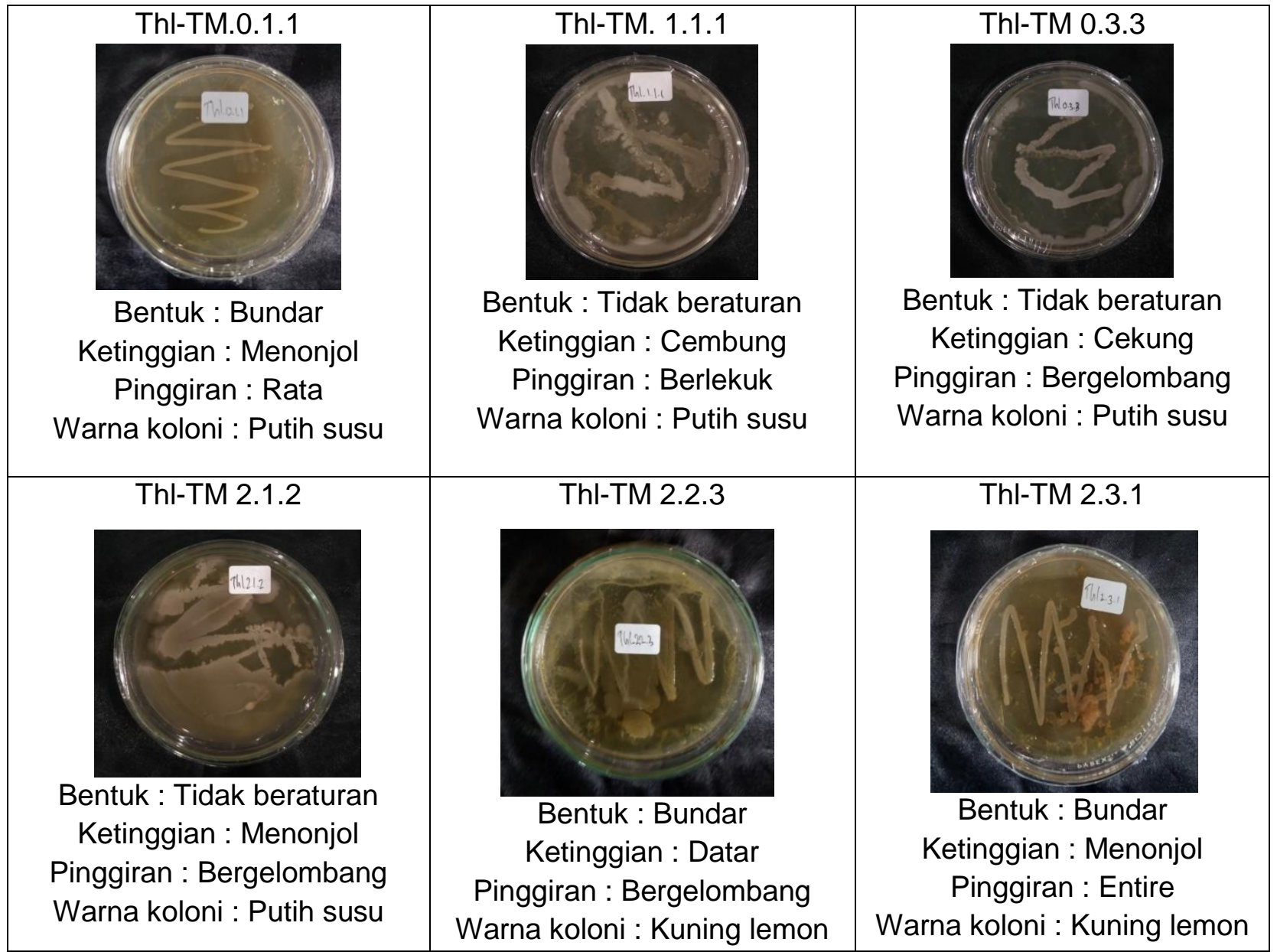




\begin{tabular}{|c|c|c|}
\hline Thl-TM 23.4 & Thl-TM 311 & Thl-TM 312 \\
\hline $\begin{array}{c}\text { Bentuk : Bundar } \\
\text { Ketinggian : Cekung } \\
\text { Pinggiran : Bergelombang } \\
\text { Warna koloni : Putih susu }\end{array}$ & $\begin{array}{c}\text { Bentuk : Bundar } \\
\text { Ketinggian : Datar } \\
\text { Pinggiran : Rata } \\
\text { Warna koloni : Putih susu }\end{array}$ & $\begin{array}{c}\text { Bentuk : Tidak beraturan } \\
\text { Ketinggian : Datar } \\
\text { Pinggiran : Berlekuk } \\
\text { Warna koloni : Putih susu }\end{array}$ \\
\hline Thl-TM 4.1.2 & Php-TM 0.2.2 & Php-TM 3.1.2 \\
\hline $\begin{array}{c}\text { Bentuk : Bundar } \\
\text { Ketinggian : Datar } \\
\text { Pinggiran : Rata } \\
\text { Warna koloni : Kuning lemon }\end{array}$ & $\begin{array}{c}\text { Bentuk : Bundar } \\
\text { Ketinggian : Datar } \\
\text { Pinggiran : Bergelombang } \\
\text { Warna koloni : Putih susu }\end{array}$ & $\begin{array}{c}\text { Bentuk : Bundar } \\
\text { Ketinggian : Datar } \\
\text { Pinggiran : Berlekuk } \\
\text { Warna koloni : Putih susu }\end{array}$ \\
\hline
\end{tabular}

Gambar 4. Karakterisasi koloni tunggal bakteri simbion Thrudilla lineolata. dan Phylidiella pustulosa.pustulosa

\section{Identifikasi Morfologi Sel Isolat Bakteri}

Berdasarkan identifikasi secara mikroskopik didapatkan 5 isolat yang Gram positif yaitu isolat Thl-TM 3.3.1, Thl-TM 2.1.2, Php-TM 3.1.2, Thl-TM 3.1.2, Thl-TM O.3.3 dan 7 isolat bakteri gram negatif yaitu isolate Thl-TM 1.1.1, Thl-TM 2.3.1, Thl-TM 0.1.1, Php-TM 0.2.2, Thl-TM 2.2.3, Thl-TM 4.1.2, Thl-TM 2.3.4 (Gambar 5) 


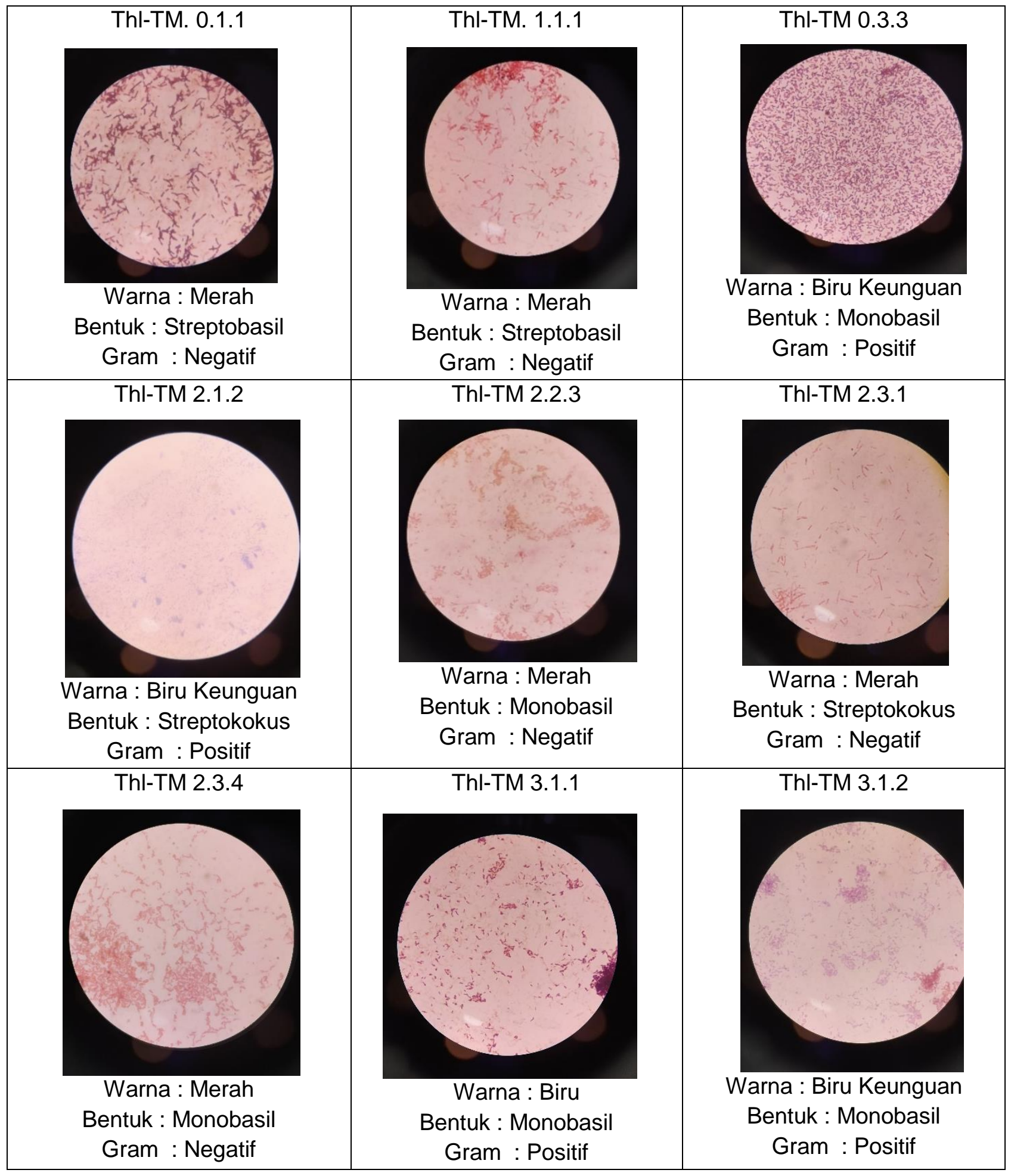




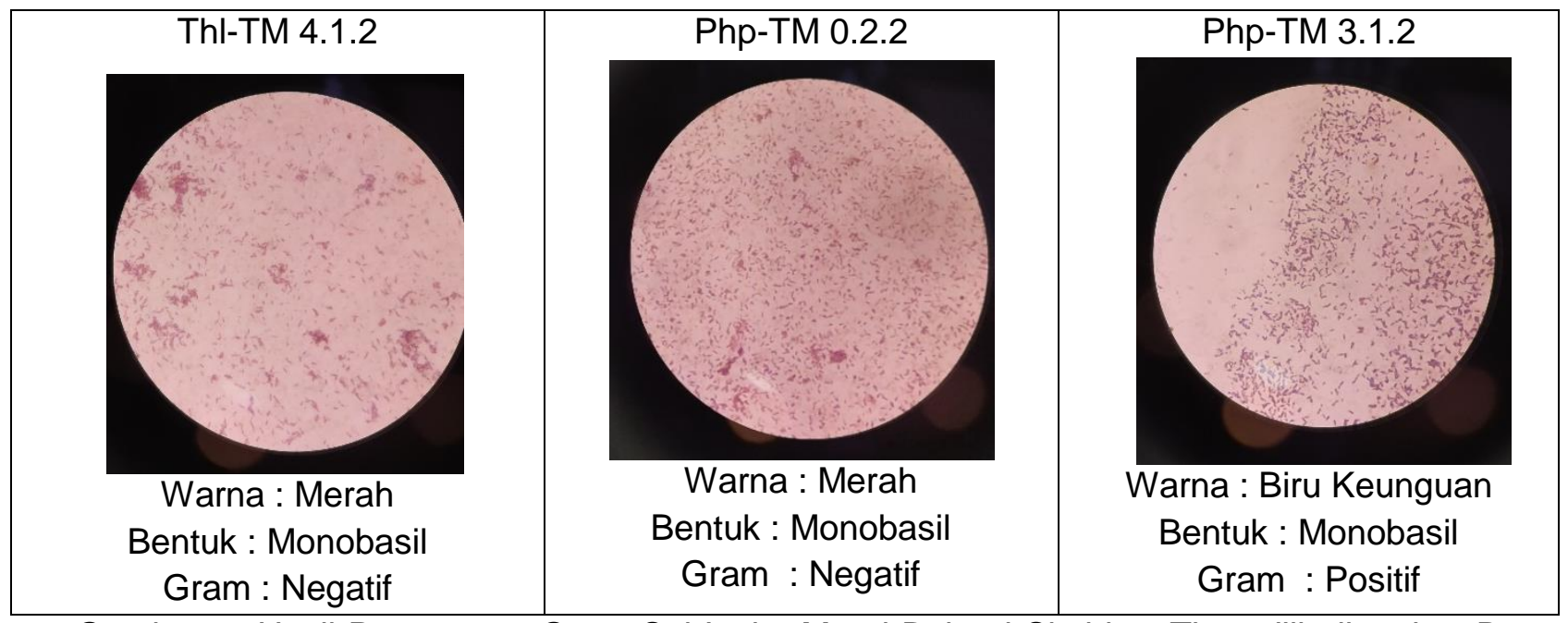

Gambar 5. Hasil Pewarnaan Gram Sel Isolat Murni Bakteri Simbion Thurudilla lineolate Dan Phylidiella pustulosa

\section{Skrining Aktivitas Antibakteri Isolat Bakteri Simbion Thurudilla lineolata dan Phyllidiella pustulosa}

Skrining aktivitas antibakteri bertujuan untuk melihat isolat yang berpotensi dalam menghasilkan senyawasenyawa yang mampu menghambat pertumbuhan bakteri patogen. Isolat bakteri dari masing-masing spesies memiliki potensi antibakteri yaitu 5 isolat bakteri dari spesies Thurudilla lineolate dan 1 isolat bakteri dari spesies Phylidiella pustulosa (Tabel 2)

Hasil pengamatan $1 \times 24$ pada isolat $1 /$ ThlTM 0.3., isolat 2/Thl-TM 2.2.3, isolat 3/ Thl-TM 2.3.1 dan isolat 6/Php-TM 0.2.2 memperlihatkan adanya aktivitas penghambatan terhadap bakteri uji $S$. aureus dan $E$. coli. Sementara pada isolat 4/ Thl-TM 4.1.2 dan isolat 5/ Thl-TM 2.1.2 menunjukkan adanya aktivitas penghambatan terhadap bakteri E.coli.
Terbentuknya zona hambat di sekitar isolat bakteri simbion Pyllidiella pustulosa dan Thrudilla lineolata menunjukan bukti bahwa isolat-isolat bakteri simbion tersubut memiliki potensi menghasilkan senyawa antibakteri dengan menghambat pertumbuhan bakteri uji.

Penelitian yang dilakukan oleh Bohringer et al. (2017), Kristiana dkk (2019), Arie dkk (2020), Dajoh $d k k$ (2020), Ukar dkk (2020) juga membuktikan bahwa bakteri terkait Nudibranch di Indonesia aktif dalam produksi senyawa antibakteri. 
Tabel 2. Hasil skrining aktivitas antibakteri dari isolat murni bakteri simbion Phylidiella pustulosa dan Thrudilla lineolata pustulosa.

\begin{tabular}{cccc}
\hline \multirow{2}{*}{ No } & Kode/ isolate & \multicolumn{2}{c}{ Bakteri Uji } \\
\cline { 3 - 4 } & & S. aureus & E. coli \\
\hline 1 & Thl-TM 0.3.3 & + & + \\
\hline 2 & Thl-TM 2.2.3 & + & + \\
\hline 3 & Thl-TM 2.3.1 & + & + \\
\hline 4 & Thl-TM 4.1.2 & - & + \\
\hline 5 & Thl-TM 2.1.2 & - & + \\
\hline 6 & Php-TM 0.2.2 & + & + \\
\hline
\end{tabular}

Metabolit sekunder yang dihasilkan dari Pyllidiella pustulosa dan Thurudilla lineolata diduga merupakan bentuk adaptasi organisme terhadap lingkungannya. Menurut Rinehart (1992) dalam Opa, $d k k$ (2018), apabila tekanan lingkungannya relatif tinggi maka senyawa yang dihasilkan akan banyak. Organisme laut, khususnya yang hidup di daerah tropis untuk kelangsungan hidupnya menghadapi berbagai tantangan, harus berkompetisi untuk mendapatkan ruang tumbuh, sinar matahari dan makanan. Metabolit sekunder yang dihasilkan mungkin bisa diproduksi sendiri oleh organisme dan bisa diproduksi dari sumber makanan.

Senyawa antibakteri dapat digolongkan juga sebagai spektrum luas dan spektrum sempit. Spektrum luas artinya senyawa tersebut bekerja aktif terhadap banyak jenis bakteri baik bakteri gram positif dan bakteri gram negatif. Sedangkan spektrum sempit artinya suatu senyawa bekerja aktif hanya terhadap satu golongan bakteri saja baik hanya pada bakteri gram positif ataupun hanya pada bakteri gram negatif (WHO, 2014). Dari hasil penelitian ini menunjukkan bahwa senyawa antibakteri Pyllidiella pustulosa dan Thurudilla lineolata termasuk berspektrum luas karena kemampuannya menghambat bakteri Gram positif dan Gram negatif.

\section{KESIMPULAN}

Berdasarkan hasil penelitian yang dilakukan, maka dapat disimpulkan bahwa:

1. Isolat bakteri yang berhasil diisolasi dari Phylidiella pustulosa dan Thurudilla lineolata sebanyak 128 koloni, terdiri dari 45 koloni tunggal dari Phylidiella pustulosa dan 83 koloni tunggal dari Thurudilla lineolata. 


\section{Jurnal Pesisir dan Laut Tropis}

2. Penapisan aktivitas antibakteri isolat murni memperlihatkan 6 isolat yang memiliki kemampuan penghambatan terhadap bakteri uji S. aureus dan E. coli.

\section{DAFTAR PUSTAKA}

Arie, A. K., R. A. J. Lintang, R. E. P. Mangindaan, A. B. Windarto, $F$. Losung, S. N. J. Longdong. 2020. Isolasi dan Skrining Aktivitas Antibakteri dan Bakteri Simbion Nudibranch Phyllidiella pustulosa dan Thuridilla lineolata. Jurnal Pesisir dan Laut Tropis. 8 (2) : 4047.

Böhringer N, Fisch KM, Schillo D, Bara R, Hertzer C, Grein F, Eisenbarth JH, KaligisF, Schneider T, Wägele H, König GM, Schäberle TF. 2017. Antimicrobial Potential of Bacteria Associated with Marine Sea Slugs from North Sulawesi, Indonesia. Front Microbiol 8: 1092. DOI: 10.3389/fmicb.2017.01092.

Dajoh, T. A. U., R. A. Bara, E. Angkouw, M. Ompi, R. A. J. Lintang, C. Lumenta. 2020. Uji Aktivitas Antibakteri dan Anti-UV Phyllidiella nigra dan Bakteri Simbiotiknya Dari Perairan Tanjung Mandolang. Jurnal Pesisir dan Laut Tropis. 8 (2) : 61-71.

Gosliner, T. M., Valdes, A., Behrens, D. W. 2018. Nudibranch \& Sea Slug Identification - Indo-Pacific - 2 nd Edition

Kristiana, R., Sibero, M. T., Farisa, M. Y., Ayuningrum, D., Dirgantara, D., Hanafi, M., Radjasa, O. K., Sabdono, A., Trianto, A. 2019.
Volume 8 Nomor 3 Tahun 2020

Antibacterial potential of nudibranch-associated bacteria from Saparua and Nusa Laut Islands, Indonesia. Biodiversitas Vol. 20, No. 7, 1811-1819.

Opa, S. L., Bara, R. A., Gerung G. S., Rompas, R. M. Lintang, R. A. J., Sumilat, D. A. 2018. Uji Aktivitas Antibakteri Fraksi N-Heksana, Metanol Dan Air Dari Ascidian Lissoclinum sp. Jurnal Pesisir dan Laut Tropis. Vol. 1. No. 1. Hal. 6980.

Pastra, D. A., Melki dan Surbaktii A. 2012. Penapisan Bakteri yang Bersimbiosis dengan Spons Jenis Aplysina sp. Sebagai Penghasil Antibakteri dari Perairan Pulau Tegal Lampung. Jurnal Maspari 4 (1): 77-82.

Pringgenies D. 2009. Bioprospeksi Bakteri Simbion Dari Gastropoda Conus miles terhadap Strain Bakteri MDR (Multi Drug Resistant). IImu Kelautan. 14 (1): 42-49.

Pringgenies D. 2010. Karakteristik Senyawa Bioaktif Bakteri Simbion Moluska dengan GC-MS. J. IImu dan TeknologiKelautanTropis. 2 (2) : 34-40.

Ukar, M. A., R. A. Bara, V. Warouw, I. F. M. Rumengan, F. Losung, M. Salaki. 2020. Aktivitas Senyawa Antibakteri dan Anti-UV Dari Phyllidia varicose (Cuvier, 1804) dan Bakteri Simbionnya (Nudibranch Gastropoda) Dari Perairan Tanjung Mandolang, Minahasa. Jurnal Pesisir dan Laut Tropis. 8 (2) : 27-39. 
Varghese, N. P. P. Joy. 2014. Microbiology Laboratory Manual Book. Kerala Agricultural University. India. Hal. 18-33.

WHO. 2014. Antmicrobial resistance: global report on survaillance 2014. World Health Organization. Hal. 257.

World Register of Marine Species (WoRMS).http://www.marinespecies .org/ (Diakses pada 02 Agustus 2020, pukul 17.30 WITA) 